\title{
Risk Attitude, Financial Knowledge and Commercial Life Insurance Needs
}

\author{
Jiaying He \\ School of Economics, Jinan University, Guangzhou, China \\ Email: hejiaying0913@163.com
}

How to cite this paper: He, J.Y. (2020) Risk Attitude, Financial Knowledge and Commercial Life Insurance Needs. Modern Economy, 11, 185-199.

https://doi.org/10.4236/me.2020.111016

Received: December 13, 2019

Accepted: January 20, 2020

Published: January 23, 2020

Copyright (C) 2020 by author(s) and Scientific Research Publishing Inc. This work is licensed under the Creative Commons Attribution International License (CC BY 4.0).

http://creativecommons.org/licenses/by/4.0/

\begin{abstract}
This paper uses the 2015 China Household Finance Survey (CHFS) to study the impact of risk attitudes and financial knowledge on household business life insurance demand from a micro perspective. By constructing the Probit and Tobit models, it is found that risk-averse families will reduce the demand for life insurance, and the increase in financial knowledge will significantly increase the participation and depth of family life insurance. It is possible to purchase commercial life insurance, and its life insurance premium expenditure industry is more. Finally, this article puts forward suggestions for promoting the development of China's commercial life insurance from the perspective of popularizing financial knowledge and providing different insurance products for different risk attitudes.
\end{abstract}

\section{Keywords}

Risk Attitude, Financial Knowledge, Commercial Life Insurance

\section{Introduction}

Insurance is one of the "three carriages" in China's financial industry. With the development of the economy, insurance plays a vital role in the Chinese economic system, and the country attaches more and more importance to insurance. In 2014, the State Council issued the "Several Opinions of the State Council on Accelerating the Development of Modern Insurance Services", and the "Ten New Articles" kicked off a new golden era for the insurance industry. In 2018, China's premium income was as high as 2724.27 billion yuan. In the ten years from 2008 to 2018, the density of commercial insurance increased from 736.75 yuan to 2724.3 yuan. The density of commercial life insurance increased from 501.38 yuan to 1485.10 yuan. The depth of commercial insurance has increased from $3.06 \%$ to $4.22 \%$, of which the depth of commercial life insurance 
has increased from $2.09 \%$ to $2.30 \%$. From the perspective of development trends, commercial life insurance and commercial insurance have the same development trend and have a greater contribution to commercial insurance. China's insurance industry predicts that by 2020, the insurance density will reach 3500 yuan, and the insurance depth will reach $5 \%$. Insurance will become a basic means of risk management and wealth management for the government, enterprises and residents, an important channel for ensuring the level and quality of protection, and an effective tool for governments to improve public services and strengthen social management. However, from the perspective of commercial life insurance density, China's life insurance premium income accounts for a low proportion of GDP. Therefore, in-depth analysis of the influencing factors of the demand for commercial life insurance from a micro perspective is of great significance to solving the problem of family protection in our country and promoting the development of the financial insurance industry.

In the past, the demand for commercial life insurance was mainly studied from the aspects of population structure and family wealth. This article mainly considers the impact of family's subjective risk attitude and financial knowledge on the demand for life insurance. Risk attitude is a variable that has fundamental significance to insurance demand. In the decision of household asset allocation, risk attitude often plays an important role. According to different risk attitudes, it can be divided into three types: risk preference, risk neutral and risk aversion. Gusio and Paiella (2008) research found that risk aversion reduces the allocation of risk assets [1]. Unlike the traditional theory that risk aversion people will choose to purchase commercial insurance to avoid risks, He Xingqiang and $\mathrm{Li}$ Tao (2009) risk attitude is significantly positively related to the demand for household commercial insurance [2]. In addition, financial knowledge also plays an important role in household financial decision-making. Rooij et al. (2011) found that lack of financial knowledge will reduce household participation in the stock market [3]. Gerrans et al. (2017) pointed out that many people who cannot accept the right financial advice and do not understand their financial knowledge level often make irrational financial decisions [4]. And financial knowledge is not the same as education level, nor can we simply equate finance with financial knowledge. So how does risk attitude and financial knowledge affect the demand for commercial life insurance in China? Therefore, this paper uses the 2015 China Household Finance Survey data to study its impact on household business life insurance demand from two perspectives: risk attitude and financial knowledge.

Therefore, this paper uses the principal component factor method to construct financial knowledge variables, and constructs a Probit model to explore the impact of risk attitudes and financial knowledge on household life insurance participation from a micro-family perspective. In addition, this article further constructs the Tobit model, and studies the impact of risk attitudes and financial knowledge on the depth of family life insurance participation, that is, the impact 
on household annual average premium expenditure. Based on the latest available 2015 household financial survey data, this article examines the impact of family risk attitudes and financial knowledge on the development of the commercial life insurance market, which will also help promote the development of China's insurance service industry.

The rest of the paper is organized as follows: Section 2 introduces the literature review, Section 3 describes the samples and variables used in this article, Section 4 gives the regression model and regression results, and Section 5 concludes.

\section{Literature Review}

Research on the impact on the demand for commercial life insurance has always been one of the key areas of concern for economic and financial scientists, and it is also one of the hot topics in the research of insurance theory in China. The factors that affect the demand for commercial life insurance in current research are mainly reflected in three aspects. First, demographic factors, such as family structure, age, gender, education level, and marital status; second, economic and financial factors, such as income status, Family financial status and social security situation; thirdly, subjective attitude factors, including risk attitude, social trust, family attitude and social interaction.

\subsection{Demographic Factors and Demand for Life Insurance}

In 1989, Lewis introduced family structure as an influencing factor for the first time in the model [5]. Brown and Kim (1993) based on the Lewis theoretical model and used data from 45 countries to perform multiple linear regression. The income level significantly promotes the demand for life insurance [6]. Antoine Bommier, Francois Le Grand (2014) studied the impact of age structure on life insurance demand, and explained why there is less demand for life insurance for the elderly over 65 years old [7]. Yin Chengyuan et al. (2008) used national time-series data analysis from 1982 to 2005 to predict the premium income of commercial life insurance [8]. Zhang Lianzeng and Shang Ying (2011) used provincial panel data from 1997 to 2008 to study the impact of population structure on China's life insurance market [9]. Fan Gangzhi and Wang Hong (2015) found that the family population structure has a significant impact on the demand for commercial life insurance [10].

\subsection{Economic and Financial Factors and Demand for Life Insurance}

Truett and Truett (1990) compared the factors influencing life insurance demand in Mexico and the United States and found that the income elasticity of Mexican life insurance demand is more than three times that of the United States [11]. Showers and Shotick (1994) found that household income, household size, and head age were significantly positively related to insurance demand 
[12]. Lin and Grace (2007) used data from the US Consumer Financial Survey to find that household vulnerability and the average age of households have a significant impact on life insurance demand [13]. Li, Moshirian and Nguyen (2007) used panel data from 30 OECD countries from 1993 to 2000 to find that per capita income, financial development, family size, education level and competition in the life insurance market will promote the demand for life insurance, while social security will suppress the demand for life insurance [14].

\subsection{Subjective Attitude Factors and Demand for Life Insurance}

The earliest empirical research by Greene (1963) found that there was no significant correlation between risk attitudes and life insurance demand [15]. Outreville (2014) reviewed relevant literature on the impact of risk attitudes on insurance demand [16]. Burnett and Palmer (1984) examined the impact of multiple subjective psychological factors on the demand for life insurance and found that traditional professional ethics, fatalism, social preferences, religious beliefs and self-confidence significantly affect the demand for life insurance [17]. In addition, many studies have found that the higher the residents' computing power and financial literacy, the higher their probability of participating in the stock market [18] [19]. A survey of Portuguese investors by Abreu and Mendes (2010) found that residents with a higher education level and higher financial literacy would better understand the decentralization of investment [20]. In terms of debt decision-making, Hilgert, Hogarth and Beverly (2003) found that respondents with low financial literacy were less likely to return credit card debts in a timely manner, and fewer people made financial budgets [21].

From the existing literature, compared with foreign studies, domestic studies are mostly analyzed from a macro perspective, and relatively few are at the micro level. Most of them directly use time series data or provincial panel data to study insurance demand issues. A few micro-perspective studies also analyze the characteristics of family population and family wealth, and there are fewer studies on family subjective risk attitudes and financial knowledge. It is difficult to judge the impact of risk attitude and financial knowledge on family business life insurance participation decision, so this article considers that it is necessary to further study this issue. At the same time, in view of previous scholars' research, this paper controls the related variables of household demographic factors and economic and financial factors, and comprehensively examines the influencing factors of household business life insurance demand.

\section{Samples and Variables}

The microdata used in this article are from the China Household Finance Survey (CHFS) project conducted by the China Family Finance Survey and Research Center of Southwestern University of Finance and Economics nationwide in 2015. The data covers 29 provinces, more than 350 counties (districts, cities), and 1048 communities (villages). It contains assets and liabilities, insurance and 
security, expenditures and income of more than 37,000 households, family demographics and employment and other detailed large-scale micro data. In addition, the macro data used in this article are from the National Bureau of Statistics of China.

Commercial life insurance participation (hold) is measured by whether the family has purchased commercial life insurance. If one or more households have purchased commercial life insurance, the family is considered to have participated in commercial life insurance (hold $=1$ ), otherwise hold $=0$. The depth of commercial life insurance participation (ln_cost) is measured by the logarithm of the average annual household life insurance premium expenditure.

It can be seen from Table 1 that the overall participation of Chinese households in commercial life insurance is low, and about $8.97 \%$ of households have purchased commercial life insurance. In addition, there is a large gap in the participation of commercial life insurance between urban and rural areas. The participation rate of urban commercial life insurance is $10.99 \%$, while the rural participation rate is only $4.52 \%$.

It can also be seen from Table 2 that the average annual difference in annual household life insurance premiums between urban and rural households in China is quite large.

This article measures the respondents' subjective risk attitude in the 2015 China Household Finance Survey Questionnaire. The question in the questionnaire is: "If you have a sum of money to invest in, which project are you most willing to choose?" If the answer is 1) high-risk, high-return project or 2) slightly higher-risk, high-return project, we consider it to be a risk appetite and assign a value of 1; if the respondent responds with 3) average risk and average return project, we consider it Risk-neutral persons are assigned a value of 2; if the respondent responds to 4) a project with slightly lower risk and slightly lower return or 5) is unwilling to take on any risk, we consider it to be a risk-averse person and assign a value of 3 . As the value increases, it indicates that respondents' risk

Table 1. Participation in Chinese family business life insurance.

\begin{tabular}{ccccc}
\hline Area & Buy life insurance & No life insurance purchased & Sum & Participation rate \\
\hline Urban & 2809 & 22,750 & 25,559 & $10.99 \%$ \\
Rural & 526 & 11,112 & 11,638 & $4.52 \%$ \\
Total & 3335 & 33,862 & 37,197 & $8.97 \%$ \\
\hline
\end{tabular}

Table 2. Annual average expenditure of commercial life insurance premiums by Chinese households.

\begin{tabular}{cc}
\hline Area & Life insurance premium expenditure (yuan/year) \\
\hline Urban & 808.76 \\
Rural & 155.79 \\
Total & 604.46 \\
\hline
\end{tabular}


aversion has increased.

From Table 3, we can see that most Chinese families are risk aversion. Of the total 33,484 households, 23,796 are risk aversion, accounting for $71.07 \%$ of the total households, and 6267 risk-neutral households, accounting for The proportion is $18.72 \%$, while the number of families with risk preference is only 3421 , accounting for only $10.22 \%$. In addition, from the perspective of urban-rural differences, urban families prefer risk, and the proportion of risk-preferred families is greater than that of rural areas, and the proportion of risk-averse families is less than that of rural areas.

This article measures the financial knowledge variables based on the five financial knowledge-related questions in the 2015 China Household Financial Questionnaire. Question one is: "How much do you usually pay attention to economic and financial information?" Question two: "Have you taken economic or financial courses?” Question three: “Assuming the bank's annual interest rate is $4 \%$, if Deposit 100 yuan of money regularly for 1 year, what is the principal and interest obtained after 1 year?" Question four: “Assume that the bank's annual interest rate is $5 \%$ and the inflation rate is $3 \%$ per year. What will happen to depositing 100 yuan in the bank for one year?"; Question five: "In general, which do you think is more risky for stocks and funds?" So according to five questions, the measurement of financial knowledge is divided into three aspects, one is financial knowledge participation, the other is financial knowledge calculation, and the third is financial knowledge understanding.

It can be seen from Table 4 that the degree of attention and participation of Chinese residents in financial knowledge is very low. The number of households who never pay attention to economic and financial information is the largest, reaching $37.84 \%$, while only $3.39 \%$ and $7.21 \%$ of the families are very concerned

Table 3. Distribution of risk attitudes among Chinese families.

\begin{tabular}{ccccccc}
\hline \multirow{2}{*}{ Area } & \multicolumn{2}{c}{ Risk appetite } & \multicolumn{2}{c}{ Risk neutral } & \multicolumn{2}{c}{ Risk aversion } \\
\cline { 2 - 6 } & $\begin{array}{c}\text { Number of } \\
\text { households }\end{array}$ & Proportion & $\begin{array}{l}\text { Number of } \\
\text { households }\end{array}$ & Proportion & $\begin{array}{c}\text { Number of } \\
\text { households }\end{array}$ & Proportion \\
\hline Urban & 2677 & $11.35 \%$ & 4815 & $20.42 \%$ & 16,093 & $68.23 \%$ \\
Rural & 744 & $7.52 \%$ & 1452 & $14.67 \%$ & 7703 & $77.82 \%$ \\
Total & 3421 & $10.22 \%$ & 6267 & $18.72 \%$ & 23,796 & $71.07 \%$ \\
\hline
\end{tabular}

Table 4. Financial knowledge participation.

\begin{tabular}{|c|c|c|c|c|c|}
\hline Variables & $\begin{array}{c}\text { Very } \\
\text { concerned }\end{array}$ & Concerned & Normally & $\begin{array}{c}\text { Rarely } \\
\text { concerned }\end{array}$ & $\begin{array}{c}\text { Never } \\
\text { concerned }\end{array}$ \\
\hline $\begin{array}{l}\text { Economic and financial } \\
\text { information attention }\end{array}$ & $3.39 \%$ & $7.21 \%$ & $22.25 \%$ & $29.32 \%$ & $37.84 \%$ \\
\hline & \multicolumn{2}{|c|}{ Yes } & \multicolumn{3}{|c|}{ No } \\
\hline $\begin{array}{c}\text { Whether to take economics } \\
\text { and finance courses? }\end{array}$ & \multicolumn{2}{|c|}{$6.63 \%$} & \multicolumn{3}{|c|}{$93.37 \%$} \\
\hline
\end{tabular}


and concerned. Only $6.63 \%$ of the families have taken economic and financial courses. At the same time, we can see from Table 5 that the percentages of Chinese residents who answered the interest rate question and the inflation question correctly were only $27.86 \%$ and $15.77 \%$. The proportion of those who did not know the answer was the largest, close to half. To sum up, the participation of Chinese household residents in financial knowledge is very low, their computing ability is not high, their understanding ability is poor, and their basic financial knowledge is relatively lacking.

This paper uses Qin Fang (2016), Meng Hongwei (2019) and other factor analysis methods to construct financial knowledge variables [22] [23]. Given that understanding financial knowledge is the premise and basis of correct calculations, this article sets two dummy variables according to interest rate calculation, inflation calculation, and investment risk calculation. The first is whether to answer the correct dummy variable, measure financial knowledge calculation, and calculate correctly Then assign a value of 1 , otherwise 0 ; the second is a virtual variable that can be understood, which measures financial knowledge understanding. If the respondent understands the relevant question (including correct/wrong options), assign a value of 1 , otherwise assign 0 (include can't count/don't know/never heard of it). At the same time, two variables are constructed based on whether to focus on economic and financial information and whether they have attended economic or financial courses to measure financial knowledge participation. Therefore, this paper constructs eight variables based on five questions and uses the principal component factor method to perform factor analysis. The results are as follows (Table 6).

Table 5. Calculation and understanding of financial knowledge.

\begin{tabular}{cccc}
\hline Variables & Correct & Wrong & Can't count/Don't know/Never heard \\
\hline Calculation of Interest rate & $27.86 \%$ & $22.40 \%$ & $49.74 \%$ \\
Calculation of Inflation Problem & $15.77 \%$ & $36.91 \%$ & $47.32 \%$ \\
Calculation of investment risk & $48.45 \%$ & $4.30 \%$ & $47.25 \%$ \\
\hline
\end{tabular}

Table 6. Factor analysis.

\begin{tabular}{cccc}
\hline Factor & Eigen value & Proportion & Cumulative \\
\hline Factor 1 & 2.65271 & 0.3316 & 0.3316 \\
Factor 2 & 1.18581 & 0.1482 & 0.4798 \\
Factor 3 & 1.09380 & 0.1367 & 0.6165 \\
Factor 4 & 0.93692 & 0.1171 & 0.7337 \\
Factor 5 & 0.82214 & 0.1028 & 0.8364 \\
Factor 6 & 0.71922 & 0.0899 & 0.9263 \\
Factor 7 & 0.50805 & 0.0635 & 0.9898 \\
Factor 8 & 0.08135 & 0.0102 & 1.0000 \\
\hline
\end{tabular}


According to the KMO test results in Table 7, the KMO value is 0.6480 , which is greater than 0.6 , and the $\mathrm{P}$ value of the Bartlett spherical test result is 0 , which can be used for factor analysis. Then judge according to the size of the characteristic value in Table 5, choose Factor 1, Factor 2, and Factor 3 greater than 1 to measure financial knowledge. Table 8 shows the descriptive statistics of financial knowledge variables.

With reference to the existing literature at home and abroad, this article also controls other factors that affect family business life insurance, including family population structure and characteristics, family wealth status, and family social security status. The structure and characteristic variables of the family population controlled in this article include total family dependency ratio, family child dependency ratio, family size, age of head of household, age squared, length of education of head of household, which takes into account that most retirement age in China is still 60 years old. The dependency ratio is expressed by the proportion of the population aged 60 years and above and the population aged 14 and under. The ratio of child support is expressed by the proportion of the population aged 14 and below. The size of the family is the total number of families and the number of years of education of the head of household is based on the education level of the respondents in the questionnaire is also given a certain number of years to measure. The value of the answer to those who have not attended school is 0 , the value of elementary school is 6 , the value of junior high is 9 , the number of high school is 12 , the number of junior high school or vocational high is 13 , college or high Is 15 , undergraduate is 16 , master degree is 19 , and doctoral degree is 22 . At the same time, dummy variables for the gender and marital status of the head of the household are set, with 1 for males and 0 for

Table 7. Factor analysis KMO test results and factor load after rotation.

\begin{tabular}{|c|c|c|c|c|}
\hline Variables & KMO & Factor 1 & Factor 2 & Factor 3 \\
\hline $\begin{array}{l}\text { Whether to pay attention to economic and } \\
\text { financial information? }\end{array}$ & 0.6647 & 0.07710 & 0.02404 & 0.70282 \\
\hline Whether to take finance courses? & 0.8173 & 0.03841 & -0.00502 & -0.55903 \\
\hline Is interest rate calculation correct? & 0.8330 & 0.01684 & 0.36540 & 0.03815 \\
\hline Do you understand interest rate issues? & 0.7763 & -0.06369 & 0.34725 & 0.26507 \\
\hline Is the inflation calculation correct? & 0.6957 & -0.16071 & 0.48262 & -0.08229 \\
\hline Do you understand inflation? & 0.7630 & 0.03747 & 0.40967 & 0.00156 \\
\hline Is the investment risk calculation correct? & 0.5784 & 0.51184 & -0.14475 & 0.05444 \\
\hline Do you understand investment risk? & 0.5823 & 0.50242 & -0.12373 & 0.03863 \\
\hline Total & 0.6480 & & & \\
\hline
\end{tabular}

Table 8. Descriptive statistics of financial knowledge.

\begin{tabular}{cccccc}
\hline Variable & Obs & Mean & Min & Max & Std. Dev. \\
\hline Financial Knowledge & 37,085 & $6.33 \mathrm{e}-18$ & -2.207 & 1.538 & 0.593 \\
\hline
\end{tabular}


females; 1 for married, and 0 for otherwise. The controlled household wealth status variables include the logarithm of annual household income, the logarithm of household net assets, and the proportion of household financial assets to total assets. In view of the existing literature research, there is both a substitute relationship and a complementary relationship between social security and commercial insurance. This article controls the social security situation of the family. The variable pension is set to indicate the proportion of family members who have social endowment insurance, and medicine indicates that family members have the proportion of social medical insurance. At the same time, as family purchase of life insurance often reflects the family members' care and attention to the family, this article sets the family importance variable (family) according to the questionnaire. The larger the family, the less important it is. In addition, this article also considers the urban and rural areas of the family. 1 means rural and 0 means urban. Descriptive statistics of variables after missing values of key variables are shown in Table 9.

\section{Empirical Analysis}

This article constructs Probit and Tobit models to empirically analyze the impact of risk attitude and financial knowledge on the participation and depth of family life insurance. Values in parentheses are z-statistics. ${ }^{* *},{ }^{* *}$, and ${ }^{*}$ indicate significant levels at $0.01,0.05$, and 0.1 , respectively.

Table 9. Descriptive statistics of the main variables.

\begin{tabular}{|c|c|c|c|c|c|c|}
\hline \multirow{2}{*}{ Variables } & \multicolumn{3}{|c|}{ No life insurance purchased } & \multicolumn{3}{|c|}{ Buy life insurance } \\
\hline & Obs & Mean & Std. Dev. & Obs & Mean & Std. Dev. \\
\hline Risk attitude & 24,000 & 2.646 & 0.642 & 2422 & 2.405 & 0.754 \\
\hline Financial knowledge & 24,000 & 0.00600 & 0.590 & 2422 & 0.300 & 0.565 \\
\hline Total depend & 24,000 & 0.385 & 0.348 & 2422 & 0.294 & 0.284 \\
\hline Child depend & 24,000 & 0.105 & 0.153 & 2422 & 0.129 & 0.162 \\
\hline Size & 24,000 & 3.560 & 1.721 & 2422 & 3.589 & 1.331 \\
\hline Edu & 24,000 & 9.098 & 4.140 & 2422 & 11.54 & 3.606 \\
\hline Age & 24,000 & 53.42 & 14.18 & 2422 & 48.43 & 12.01 \\
\hline Gender & 24,000 & 0.765 & 0.424 & 2422 & 0.725 & 0.447 \\
\hline Married & 24,000 & 0.860 & 0.347 & 2422 & 0.906 & 0.292 \\
\hline Income & 24,000 & 65,000 & 260,000 & 2422 & 160,000 & 500,000 \\
\hline Net asset & 24,000 & 660,000 & $1.500 \mathrm{e}+06$ & 2422 & $1.600 \mathrm{e}+06$ & $2.600 \mathrm{e}+06$ \\
\hline Finance & 24,000 & 11000 & 7283 & 2422 & 14000 & 6473 \\
\hline Pension & 24,000 & 29.25 & 14.51 & 2422 & 31.78 & 12.63 \\
\hline Medicine & 24,000 & 0.938 & 0.163 & 2422 & 0.961 & 0.123 \\
\hline Family & 24,000 & 1.403 & 0.640 & 2422 & 1.264 & 0.516 \\
\hline Rural & 24,000 & 0.336 & 0.472 & 2422 & 0.166 & 0.373 \\
\hline
\end{tabular}




\subsection{Risk Attitude, Financial Knowledge and Participation in Commercial Life Insurance}

Using the above data and variables, in order to verify the impact of risk attitude and financial knowledge on the purchase decision of commercial life insurance, this paper builds the following Probit model:

$\operatorname{Pr}($ hold $=1)=\Phi\left(\beta_{0}+\beta_{1}\right.$ risk_attitude $+\beta_{2}$ financial_knowledge $+\gamma$ controls $\left.+\varepsilon\right)$

In formula (1), hold indicates whether the household holds commercial life insurance, 1 indicates holding, and 0 indicates not. Risk_attitude and financial_knowledge are the two variables concerned in this article, which represent the family's risk attitude and financial knowledge. The measurement methods are described in Section 2. Controls represent all control variables. Table 10 shows the Probit model of the impact of risk attitudes and financial knowledge on household business life insurance holdings.

The results in the first column of Table 10 indicate that the risk attitude has a significantly negative effect on the demand for family life insurance, that is, as the degree of risk aversion increases, the family's demand for commercial life insurance decreases. Smaller-risk family lifestyles require less risk and are more willing to hold money in their hands, and the demand for life insurance will also be lower. The results of the second column show that financial knowledge has a positive impact on the demand for family life insurance. It can be seen that increasing the popularity of financial knowledge is very important to increase the participation of commercial life insurance.

From the perspective of controlling variables, the total family dependency ratio and the child dependency ratio have opposite effects on family life insurance demand. On the one hand, the higher the proportion of children aged 14 and under, the greater the demand for family life insurance. In order to protect and protect the children in the family, worrying that children's life and education will not be guaranteed when the family encounters a change, so they are more inclined to purchase life insurance for themselves. The total dependency ratio has a suppressive effect on the demand for life insurance. This is mainly because the elderly population in the family cannot participate in life insurance purchases because they are older than a certain age or suffer from certain diseases, which has curtailed the demand for life insurance products. From the personal characteristics of the head of household, the higher the education level of the head of household, the greater the demand for life insurance products; the coefficient of the primary term of the head of the household is significantly positive, and the coefficient of the quadratic term is significantly negative; The effect of gender on life insurance demand is significantly negative, indicating that female heads of households have greater demand for life insurance. As far as the family's financial situation is concerned, the average annual household income, household net assets and the proportion of financial assets in total assets will affect the ability to pay for insurance, thereby promoting participation in life insurance. At the same time, the demand for life insurance in rural households is much smaller than 
Table 10. Impact of risk attitude and financial knowledge on commercial life insurance participation.

\begin{tabular}{|c|c|c|c|}
\hline Variables & Probit 1 & Probit 2 & Probit 3 \\
\hline \multirow[t]{2}{*}{ Risk attitude } & $-0.068^{\star * *}$ & & $-0.066^{\star * *}$ \\
\hline & $(-3.81)$ & & $(-3.71)$ \\
\hline \multirow[t]{2}{*}{ Financial knowledge } & & $0.163^{* * *}$ & $0.161^{* * *}$ \\
\hline & & $(7.30)$ & $(7.25)$ \\
\hline \multirow[t]{2}{*}{ Total depend } & $-0.125^{\star \star}$ & $-0.128^{\star *}$ & $-0.123^{* *}$ \\
\hline & $(-2.08)$ & $(-2.12)$ & $(-2.03)$ \\
\hline \multirow[t]{2}{*}{ Child depend } & $0.445^{\star * *}$ & $0.440^{* * *}$ & $0.427^{\star * *}$ \\
\hline & $(4.22)$ & $(4.16)$ & $(4.04)$ \\
\hline \multirow[t]{2}{*}{ Size } & 0.000 & 0.002 & 0.002 \\
\hline & $(0.03)$ & $(0.20)$ & $(0.23)$ \\
\hline \multirow[t]{2}{*}{ Edu } & $0.030^{* * *}$ & $0.028^{* * *}$ & $0.027^{* * *}$ \\
\hline & $(7.51)$ & $(7.08)$ & $(6.79)$ \\
\hline \multirow[t]{2}{*}{ Age } & $0.051^{* * *}$ & $0.050^{* * *}$ & $0.052^{\star * *}$ \\
\hline & $(7.45)$ & $(7.26)$ & $(7.46)$ \\
\hline \multirow[t]{2}{*}{ Age_2 } & $-0.000^{\star * *}$ & $-0.000^{* * *}$ & $-0.000^{\star * *}$ \\
\hline & $(-7.22)$ & $(-7.03)$ & $(-7.16)$ \\
\hline \multirow[t]{2}{*}{ Gender } & $-0.099^{* * *}$ & $-0.091^{\star * *}$ & $-0.096^{\star * *}$ \\
\hline & $(-3.40)$ & $(-3.13)$ & $(-3.30)$ \\
\hline \multirow[t]{2}{*}{ Married } & 0.008 & -0.010 & 0.002 \\
\hline & $(0.18)$ & $(-0.22)$ & $(0.04)$ \\
\hline \multirow[t]{2}{*}{ Ln_income } & $0.058^{\star * *}$ & $0.060^{\star * *}$ & $0.057^{\star * *}$ \\
\hline & $(5.93)$ & $(6.07)$ & $(5.79)$ \\
\hline \multirow[t]{2}{*}{ Ln_net_asset } & $0.167^{* * *}$ & $0.165^{\star * *}$ & $0.161^{\star * *}$ \\
\hline & (15.98) & (15.69) & $(15.23)$ \\
\hline \multirow[t]{2}{*}{ Finance } & $0.000^{* * *}$ & $0.000^{* * *}$ & $0.000^{* * *}$ \\
\hline & $(11.72)$ & $(11.31)$ & $(10.89)$ \\
\hline \multirow[t]{2}{*}{ Rural } & $-0.063^{*}$ & -0.033 & -0.034 \\
\hline & $(-1.84)$ & $(-0.95)$ & $(-0.99)$ \\
\hline \multirow[t]{2}{*}{ Family } & $-0.110^{\star * *}$ & $-0.109^{* * *}$ & $-0.110^{* * *}$ \\
\hline & $(-4.91)$ & $(-4.89)$ & $(-4.89)$ \\
\hline \multirow[t]{2}{*}{ Pension } & -0.000 & -0.001 & -0.001 \\
\hline & $(-0.44)$ & $(-0.64)$ & $(-0.66)$ \\
\hline \multirow[t]{2}{*}{ Medicine } & $0.330^{* * *}$ & $0.349^{* * *}$ & $0.345^{\star * *}$ \\
\hline & $(3.37)$ & $(3.54)$ & $(3.50)$ \\
\hline \multirow[t]{2}{*}{ Constant } & $-5.817^{\star * *}$ & $-5.956^{* * *}$ & $-5.737^{\star * *}$ \\
\hline & $(-23.78)$ & $(-24.95)$ & $(-23.36)$ \\
\hline Observations & 22,411 & 22,411 & 22,411 \\
\hline Pseudo $\mathrm{R}^{2}$ & 0.1080 & 0.1107 & 0.1116 \\
\hline
\end{tabular}


that in urban households, and the higher the importance of family members, the greater the demand for life insurance.

\subsection{Risk Attitude, Financial Knowledge and Depth of Participation in Commercial Life Insurance}

In this article, the average annual household premium expenditure is used to measure the depth of participation of family life insurance. Since the family premium expenditure of non-purchased life insurance is 0 , that is, the dependent variable data is truncated, the Tobit model is used to estimate the risk attitude and financial knowledge for family life insurance the impact of engagement depth.

$$
\begin{gathered}
\text { LnCost }^{*}=\beta_{0}+\beta_{1} \text { risk_attitude }+\beta_{2} \text { knowledge }+\gamma \text { Controls }+\varepsilon \\
\text { LnCost }=\operatorname{Max}\left(0, \text { LnCost }^{*}\right)
\end{gathered}
$$

Among them, LnCost represents the logarithmic value of the actual life insurance premium expenditure of the family last year, LnCost ${ }^{*}$ represents the observed value when LnCost is greater than 0 , and other variables are the same as in formula (1). The regression results are shown in Table 11.

As can be seen from Table 11, the coefficient of risk attitude is still negative and significant at the $1 \%$ level. The impact of financial knowledge on the depth of life insurance participation is still significantly positive. The regression results of other control variables are consistent with the conclusions of the Probit model.

Finally, we performed a robustness test on the benchmark regression model. We divided the entire sample households into sub-samples according to urban and rural areas for regression, and then divided the full sample into eastern, central, and western households based on the location of the family for Probit and Tobit regression. The regression results are basically consistent with the results of using the full sample regression.

\section{Conclusions and Implications}

Based on the data of the 2015 China Household Finance Survey, this article empirically analyzes the impact of risk attitudes and financial knowledge on the demand for family business life insurance from a micro perspective. This is also one of the innovations of this article. This article examines the risks while testing traditional interpretation, the impact of attitudes and financial knowledge on household business life insurance demand. The results show that increased risk aversion has dampened the demand for family life insurance, and increased financial knowledge has promoted the purchase of family life insurance. Further research also found that the degree of risk aversion has a significant negative impact on the depth of life insurance participation, and financial knowledge has a significant positive impact on the depth of life insurance participation, that is, families with a higher risk appetite or families with a higher level of financial knowledge. The average annual premium expenditure is also higher. In addition, 
Table 11. Impact of risk attitude and financial knowledge on the depth of commercial life insurance participation.

\begin{tabular}{|c|c|c|c|}
\hline Variables & Tobit 1 & Tobit 2 & Tobit 3 \\
\hline \multirow[t]{2}{*}{ Risk attitude } & $-0.838^{* * *}$ & & $-0.818^{* * *}$ \\
\hline & $(-3.40)$ & & $(-3.33)$ \\
\hline \multirow[t]{2}{*}{ Financial knowledge } & & $2.014^{\star * *}$ & $2.000^{\star * *}$ \\
\hline & & $(6.49)$ & $(6.45)$ \\
\hline \multirow[t]{2}{*}{ Total depend } & $-2.649^{* * *}$ & $-2.701^{* * *}$ & $-2.645^{\star * *}$ \\
\hline & $(-3.06)$ & $(-3.11)$ & $(-3.05)$ \\
\hline \multirow[t]{2}{*}{ Child depend } & $8.723^{\star * *}$ & $8.685^{\star * *}$ & $8.531^{* * *}$ \\
\hline & $(5.95)$ & $(5.92)$ & $(5.82)$ \\
\hline \multirow[t]{2}{*}{ Size } & 0.012 & 0.036 & 0.039 \\
\hline & $(0.09)$ & $(0.26)$ & $(0.28)$ \\
\hline \multirow[t]{2}{*}{ Edu } & $0.382^{* * *}$ & $0.365^{\star * *}$ & $0.350^{\star * *}$ \\
\hline & $(6.80)$ & $(6.48)$ & $(6.22)$ \\
\hline \multirow[t]{2}{*}{ Age } & $0.811^{* * *}$ & $0.795^{\star * *}$ & $0.812^{\star * *}$ \\
\hline & $(7.96)$ & $(7.81)$ & $(7.97)$ \\
\hline \multirow[t]{2}{*}{ Age_2 } & $-0.008^{* * *}$ & $-0.008^{* * *}$ & $-0.008^{* * *}$ \\
\hline & $(-7.88)$ & $(-7.74)$ & $(-7.84)$ \\
\hline \multirow[t]{2}{*}{ Gender } & $-1.158^{* * *}$ & $-1.062^{\star * *}$ & $-1.122^{* * *}$ \\
\hline & $(-2.86)$ & $(-2.63)$ & $(-2.78)$ \\
\hline \multirow[t]{2}{*}{ Married } & 0.325 & 0.084 & 0.229 \\
\hline & $(0.51)$ & $(0.13)$ & $(0.36)$ \\
\hline \multirow[t]{2}{*}{ Ln_income } & $0.614^{\star * *}$ & $0.630^{\star * *}$ & $0.596^{\star * *}$ \\
\hline & $(4.49)$ & $(4.61)$ & $(4.36)$ \\
\hline \multirow[t]{2}{*}{ Ln_net_asset } & $2.193^{* * *}$ & $2.163^{* * *}$ & $2.106^{\star * *}$ \\
\hline & $(14.46)$ & $(14.28)$ & $(13.87)$ \\
\hline \multirow[t]{2}{*}{ Finance } & $0.000^{* * *}$ & $0.000^{\star * *}$ & $0.000^{* * *}$ \\
\hline & (10.39) & $(10.07)$ & $(9.70)$ \\
\hline \multirow[t]{2}{*}{ Rural } & $-0.951^{* *}$ & -0.571 & -0.588 \\
\hline & $(-1.99)$ & $(-1.18)$ & $(-1.22)$ \\
\hline \multirow[t]{2}{*}{ Family } & $-1.443^{* * *}$ & $-1.441^{* * *}$ & $-1.442^{* * *}$ \\
\hline & $(-4.60)$ & $(-4.58)$ & $(-4.59)$ \\
\hline \multirow[t]{2}{*}{ Pension } & -0.007 & -0.010 & -0.010 \\
\hline & $(-0.52)$ & $(-0.69)$ & $(-0.71)$ \\
\hline \multirow[t]{2}{*}{ Medicine } & $4.057^{* * *}$ & $4.302^{* * *}$ & $4.262^{\star * *}$ \\
\hline & $(2.97)$ & (3.13) & $(3.10)$ \\
\hline \multirow[t]{2}{*}{ Constant } & $-79.000^{* * *}$ & $-80.765^{\star * *}$ & $-77.891^{\star * *}$ \\
\hline & $(-20.95)$ & $(-21.82)$ & $(-20.67)$ \\
\hline Observations & 22,411 & 22,411 & 22,411 \\
\hline Pseudo $\mathrm{R}^{2}$ & 0.0586 & 0.0599 & 0.0603 \\
\hline
\end{tabular}


an increase in the average annual household income, an increase in the family's net assets, and an increase in the proportion of financial assets in total assets will promote the family's demand for commercial life insurance. The family dependency ratio, the age, gender, and education level of the head of households also contribute to family life insurance. Participation and depth of participation have important implications.

Based on the research conclusions of this paper, two suggestions are made for the development of China's commercial life insurance: First, the government and financial institutions should increase the education and popularization of financial knowledge, increase the promotion and promotion of financial knowledge, and organize professionals to conduct financial knowledge explanation, improve the enthusiasm and initiative of residents to learn financial knowledge, so as to increase the participation and depth of households in commercial life insurance. Second, consider the differences in family attitudes to risk, and recommend and explain different types of commercial life insurance, make full use of insurance protection and investment functions, and ensure that families with various risk attitudes actively participate in the rational and scientific purchase of commercial life insurance. China, thus promoting the healthy development of China's insurance industry.

In addition, due to the limited data, the research in this paper also has certain limitations. The impact of family risk attitudes on the demand for life insurance is significantly negative, that is, the increase in risk aversion has suppressed the demand for life insurance. The characteristics of insurance with insurable functions are inconsistent. This may be due to the impact of different risk attitudes on different types of insurance. Further research requires more detailed data, which is also the direction of our further research.

\section{Conflicts of Interest}

The author declares no conflicts of interest regarding the publication of this paper.

\section{References}

[1] Guiso, L. and Paiella, M. (2008) Risk Aversion, Wealth and Background Risk. Journal of the European Economic Association, 6, 1109-1150. ttps://doi.org/10.1162/JEEA.2008.6.6.1109

[2] He, X.Q. and Li, Tao. (2009) Social Interaction, Social Capital and Commercial Insurance Purchase. Financial Research, 2, 116-132.

[3] Rooij, M., Lusardi, A. and Alessie, R. (2011) Financial Literacy and Stock Market Participation. Journal of Financial Economics, 101, 449-472. https://doi.org/10.1016/j.jfineco.2011.03.006

[4] Gerrans, P. and Hershey, D.A. (2017) Financial Adviser Anxiety, Financial Literacy and Financial Advice Seeking. Journal of Consumer Affairs, 51, 54-90. https://doi.org/10.1111/joca.12120

[5] Lewis, F.D. (1989) Dependents and the Demand for Life Insurance. The American Economic Review, 79, 452-467.

[6] Kim, K. and Brown, M. (1993) An International Analysis of Life Insurance De- 
mand. Journal of Risk and Insurance, 60, 616-634.

https://doi.org/10.2307/253382

[7] Antoine Bommier, F.G. (2014) Too Risk Averse to Purchase Insurance? A Theoretical Glance at the Annuity Puzzle. Journal of Risk and Uncertainty, 48, 135-166. https://doi.org/10.1007/s11166-014-9190-3

[8] Yin, C.Y., Zhao, G.L. and Zhou, W.H. (2008) Empirical Analysis and Prediction of Life Insurance Premium Income in China. Insurance Research, 1, 48-52.

[9] Zhang, L.Z. and Shang, Y. (2011) Analysis of the Impact of China's Population Aging on the Development of Life Insurance Market-An Empirical Analysis Based on the Panel Data of Provinces. Insurance Research, 1, 46-53.

[10] Fan, G.Z. and Wang, H.Y. (2015) Family Population Structure and Family Business Life Insurance Demands-An Empirical Study Based on China Household Financial Survey (CHFS) Data. Financial Research, 7, 170-189.

[11] Truett, D.B. and Truett, L.J. (1990) The Demand for Life Insurance in Mexico and the United States: A Comparative Study. Journal of Risk and Insurance, 57, 321-328. https://doi.org/10.2307/253306

[12] Showers, V.E. and Shotick, J.A. (1994) The Effects of Household Characteristics on Demand for Insurance: A Tobit Analysis. Journal of Risk and Insurance, 61, 492-502. https://doi.org/10.2307/253572

[13] Lin, Y. and Grace, M.F. (2007) Household Life Cycle Protection: Life Insurance Holdings, Financial Vulnerability and Portfolio Implications. Journal of Risk and Insurance, 74, 141-173. https://doi.org/10.1111/j.1539-6975.2007.00205.x

[14] Li, D., Moshirian, F., Nguyen, P. and Wee, T. (2007) The Demand for Life Insurance in OECD Countries. Journal of Risk and Insurance, 74, 637-652. https://doi.org/10.1111/j.1539-6975.2007.00228.x

[15] Greene, M.R. (1963) Attitude toward Risk and a Theory of Insurance Consumption. Journal of Insurance, 30, 165-182. https://doi.org/10.2307/250418

[16] Outreville, J.F. (2014) Risk Aversion, Risk Behavior, and Demand for Insurance: A Survey. Journal of Insurance Issues, 37, 158-186. https://doi.org/10.2139/ssrn.2363877

[17] Burnett, J.J. and Palmer, B.A. (1984) Examining Life Insurance Ownership through Demographic and Psychographic Characteristics. Journal of Risk and Insurance, 51, 453-467. https://doi.org/10.2307/252479

[18] Christiansen, C., Joensen, J.S. and Rangvid, J. (2008) Are Economists More Likely to Hold Stocks? Review of Finance, 12, 465-496. https://doi.org/10.1093/rof/rfm026

[19] van Rooij, M., Lusardi, A. and Alessie, R. (2011) Financial Literacy and Stock Market Participation. Journal of Financial Economics, 101, 449-472. https://doi.org/10.1016/j.jfineco.2011.03.006

[20] Abreu, M. and Mendes, V. (2010) Financial Literacy and Portfolio Diversification. Quantitative Finance, 10, 515-528. https://doi.org/10.1080/14697680902878105

[21] Hilgert, M.A., Hogarth, J.M. and Beverly, S.G. (2003) Household Financial Management: The Connection between Knowledge and Behavior. Federal Reserve Bulletin, 89, 309-322.

[22] Qin, F., Wang, W.C. and He, J.C. (2016) The Impact of Financial Knowledge on Commercial Insurance Participation: An Empirical Analysis from China Household Financial Survey (CHFS) Data. Financial Research, 10, 143-158.

[23] Meng, H.W. (2019) The Impact of Financial Knowledge on Commercial Endowment Insurance Participation. Financial Development Review, 1, 148-158. 